Dhaka Univ. J. Biol. Sci. 21(1): 1-7, 2012 (January)

\title{
BACTERIOLOGICAL, PHYSICAL AND CHEMICAL PROPERTIES OF THE PAGLA SEWAGE TREATMENT PLANT'S WATER
}

\author{
Mihir Lal SahA*, Ashraful Alam, Mahbubar Rahman Khan and Sirajul Hoque ${ }^{1}$ \\ Laboratory of Microbiology, Department of Botany, University of Dhaka, \\ Dhaka-1000, Bangladesh
}

Key words: Bacteria, Chemical properties, Treatment plant, Sewage

\begin{abstract}
Samples from Pagla sewage treatment plant at different treatment stages showed more or less similar temperature $\left(26.9-27.5^{\circ} \mathrm{C}\right)$. The $\mathrm{pH}$ ranged from 7.2 - 7.9. Influent water and primary sedimentation tank water were brownish in colour while sludge water was light black. The lagoon water and treated water were greenish. The ammonium-nitrogen $\left(\mathrm{NH}_{4}^{+}-\mathrm{N}\right)$ and nitrate-nitrogen $\left(\mathrm{NO}_{3}^{-}-\mathrm{N}\right)$ ranged from $5.24-61.94 \mathrm{mg} / \mathrm{l}$ and $2.55-11.02 \mathrm{mg} / \mathrm{l}$, respectively. Phosphorus of the water was $1.34-4.50 \mathrm{mg} / \mathrm{l}$. The suspended solids (SS) ranged from 25.48 $374.69 \mathrm{mg} / \mathrm{l}$. In the present study the amount of SS in the treated water were found to be quite satisfactory. The total bacterial population in Pagla sewage treatments plant was in between $2.9 \times 10^{4}$ and $2.5 \times 10^{6} \mathrm{cfu} / \mathrm{ml}$. The qualitative bacterial spectrum showed a potential consortium of bacteria associated with the treatment plant. Both Gram positive and Gram negative bacteria were present. Gram positive bacteria were represented by the different species of the genus Bacillus, Aureobacterium and Kurthia. Among them Bacillus was the dominant genus. The different species of Bacillus were Bacillus sphaericus, B. fastidiosus, B. circulans and B. pasteurii. Gram negative bacteria were Zoogloea, Yersinia, Citrobacter and Pseudomonas. A good number of microorganisms were found to be associated with the bio-oxidation of the organic compounds of the influent. The Zoogloea along with other free flowing aerobic heterotrophic bacteria like Bacillus, Pseudomonas could play the major role in the sewage treatment.
\end{abstract}

\section{Introduction}

Water has always been a vital item for man's existence and it's uses for drinking, cooking, agriculture, industry, transport and recreation show immediately the extent to which it is an integral part of our life. The volume of water is being contaminated and increasing with growth in population and in the industrial use of water ${ }^{(1)}$. The world is now facing the problem of water pollution caused by xenobiotic chemicals. A large variety of chemicals have entered into the environment as a result of our daily activities $^{(2)}$. Improper disposal of wastewater has led to surface water and ground water contamination ${ }^{(3)}$. Contaminating sources are not easily identifiable and their effects are

\footnotetext{
*Corresponding author: <sahaml@yahoo.com>.

${ }^{1}$ Department of Soil, Water and Environment, University of Dhaka, Dhaka-1000, Bangladesh.
} 
realized only when a level of deterioration below the usable level has been observed ${ }^{(4)}$. In the environment, bacteria demonstrate a great degree of metabolic versatility. The structure of a bacterial community in the aquatic environment is dependent on both physical and chemical conditions of their habitats ${ }^{(5)}$.

Activated sludge is currently the most widely used process for the treatment of both domestic and industrial wastewaters and at least by scale, one of the most important microbiological technologies. A regular microscopic and enzymatic investigation of activated sludge and biofilms could improve the assessment of the stability of the progress and support troubles in wastewater treatment plants(6). Taber (1976) studied different aspects of microorganisms in waters, optimization of conversion of wastes, treatment of industrial and agricultural waste with the production of energy and fertilizer and development of lagoon systems and biological treatment of wastes( ${ }^{(7)}$. To meet existing and future effluent license commitments, wastewater treatment plants worldwide are required to more efficiently remove nutrients such as phosphorus. Removal of a portion of the growing biomass (waste-activated sludge) results in the net removal of phosphorus from the wastewater ${ }^{(8)}$. The present work was undertaken to determine the physical and chemical nature and the bacteria associated with the wastewater and treated water of the wastewater treatment plant of Pagla, Narayanganj, Dhaka, Bangladesh.

\section{Materials and Methods}

Water samples were collected from five different stages viz. influent, primary sedimentation tank, sludge water, lagoon water, treated water of Pagla wastewater treatment plant. The colour and temperature of the samples were recorded carefully at the time of sampling while $\mathrm{pH}$ of the samples was measured in the laboratory with an electric pH meter (Jenway 3310, U.K.) immediately. Samples were preserved in a refrigerator at $4^{\circ} \mathrm{C}$ before and after the microbial analysis. The isolation of bacteria was done as soon as possible after collection of samples. The bacterial colonies were isolated by decimal dilution plate procedure ${ }^{(9)}$. For isolation of aerobic heterotrophic bacteria, nutrient agar (NA) medium was used and the $\mathrm{pH}$ of the medium was adjusted to 7.0.

After 24 hours of incubation, the plate having 30 - 300 colonies were selected for counting and isolation of bacteria. The selected plates were placed in a colony counter (Digital colony counter, DC-3, OSK 10086, Kayagaki, Japan) and the colonies were counted. The viable bacterial count per $\mathrm{ml}$ was calculated by multiplying the average number of colonies per plate by the reciprocal of the dilution ${ }^{(10)}$. The results would be as colony forming units $\mathrm{cfu} / \mathrm{ml}$ water sample. Isolation of the selected colonies was carried out immediately after counting the colonies. The selected isolates were then purified through repeated streaking on nutrient agar plate. Biochemical and physiological tests were carried out for the identification of the isolated bacteria ${ }^{(10-15)}$. 
For the estimation of suspended solids (SS) the collected samples were centrifuged for 10 minutes at 10,000 $\mathrm{rpm}$. The precipitations were taken in the porcelain cups and dried in an oven at $100^{\circ} \mathrm{C}$ till constant weight. Suspended solids were calculated by subtracting the initial weight from final weight. Ammonium-nitrogen and nitratenitrogen of the samples were determined following Kjeldahl's distillation method as described by Jackson (1973) and colorimetric method (Joergensen and Brookes 1990), respectively. Phosphorus present in the samples was determined by ascorbic acid blue colour method (Murphy and Riley 1962)(16-18).

\section{Results and Discussion}

Table 1 shows the temperature, colour, $\mathrm{pH}$ and total viable aerobic bacteria of the water samples. The temperatures of the samples were more or less similar $\left(26.9-27.5^{\circ} \mathrm{C}\right)$. The $\mathrm{pH}$ was found to be slightly alkaline (7.2 - 7.9). Similar results were also reported by other workers ${ }^{(19,20)}$. Influent water and primary sedimentation tank water were brownish while sludge water was light black. The colour of lagoon water and treated water were greenish. The ammonium-nitrogen ranged from $5.24-61.94 \mathrm{mg} / \mathrm{l}$ and nitrate-nitrogen ranged from $2.55-11.02 \mathrm{mg} / \mathrm{l}$. The result clearly showed that ammonium-nitrogen was higher than nitrate-nitrogen. Ammonia in the environment originates from metabolic, agricultural and industrial processes. Ammonia in water is an indicator of possible bacterial, sewage and animal waste pollution. Natural levels in ground and surface waters are usually below $0.2 \mathrm{mg} / \mathrm{l}^{(21)}$. Effluent guidelines and standards have been adopted for environmental health standards by different countries like Environmental Protection Agency (EPA) of the USA which has prescribed tolerance limit for the liquid effluents i.e. temperature $\left(20^{\circ} \mathrm{C}\right), \mathrm{NH}_{4}-\mathrm{N}(0.5 \mathrm{mg} / \mathrm{l}), \mathrm{NO}_{3}-\mathrm{N}(1.0 \mathrm{mg} / \mathrm{l})$. Suggestion made by the Bureau of Indian Standards for liquid effluents are temperature $40-45^{\circ} \mathrm{C}$, pH 5.5 to $9.0, \mathrm{NH}_{4}{ }^{+}-\mathrm{N} 50 \mathrm{mg} / \mathrm{l}$ (max.) (22). In Bangladesh, standards for industrial effluents particularly for $\mathrm{pH}$, temperature, $\mathrm{NH}_{4}{ }^{+}-\mathrm{N}, \mathrm{NO}_{3}-\mathrm{N}$ and phosphorus are $6.5-8.5,40^{\circ} \mathrm{C}, 50$, 10 , and $8 \mathrm{mg} / \mathrm{l}$, respectively ${ }^{(23)}$.

In this study it was found that influent water and sludge water showed elevated level of $\mathrm{NH}_{4}{ }^{+}-\mathrm{N}$ but the values of treated water were within the safe limit. Phosphorus of the water samples of different stages of the treatment plant varied from 1.34 to $4.50 \mathrm{mg} / \mathrm{l}$. The suspended solids (SS) ranged from 25.48 to $374.69 \mathrm{mg} / \mathrm{l}$. The United Kingdom Royal Commission on sewage disposal of 1898 - 1915 suggested that the SS level should be less than $30 \mathrm{mg} / \mathrm{l}$. In the present study the amount of SS in the treated water were found to be satisfactory. The total viable aerobic heterotrohic bacteria ranged between $2.9 \times 10^{4}$ and $2.5 \times 10^{6} \mathrm{cfu} / \mathrm{ml}$. The highest load $\left(2.5 \times 10^{6} \mathrm{cfu} / \mathrm{ml}\right)$ was observed in the primary sedimentation tank while the lowest count $\left(2.9 \times 10^{4} \mathrm{cfu} / \mathrm{ml}\right)$ was found in the treated water. Microbial load is one of the important features in biological wastewater treatment 


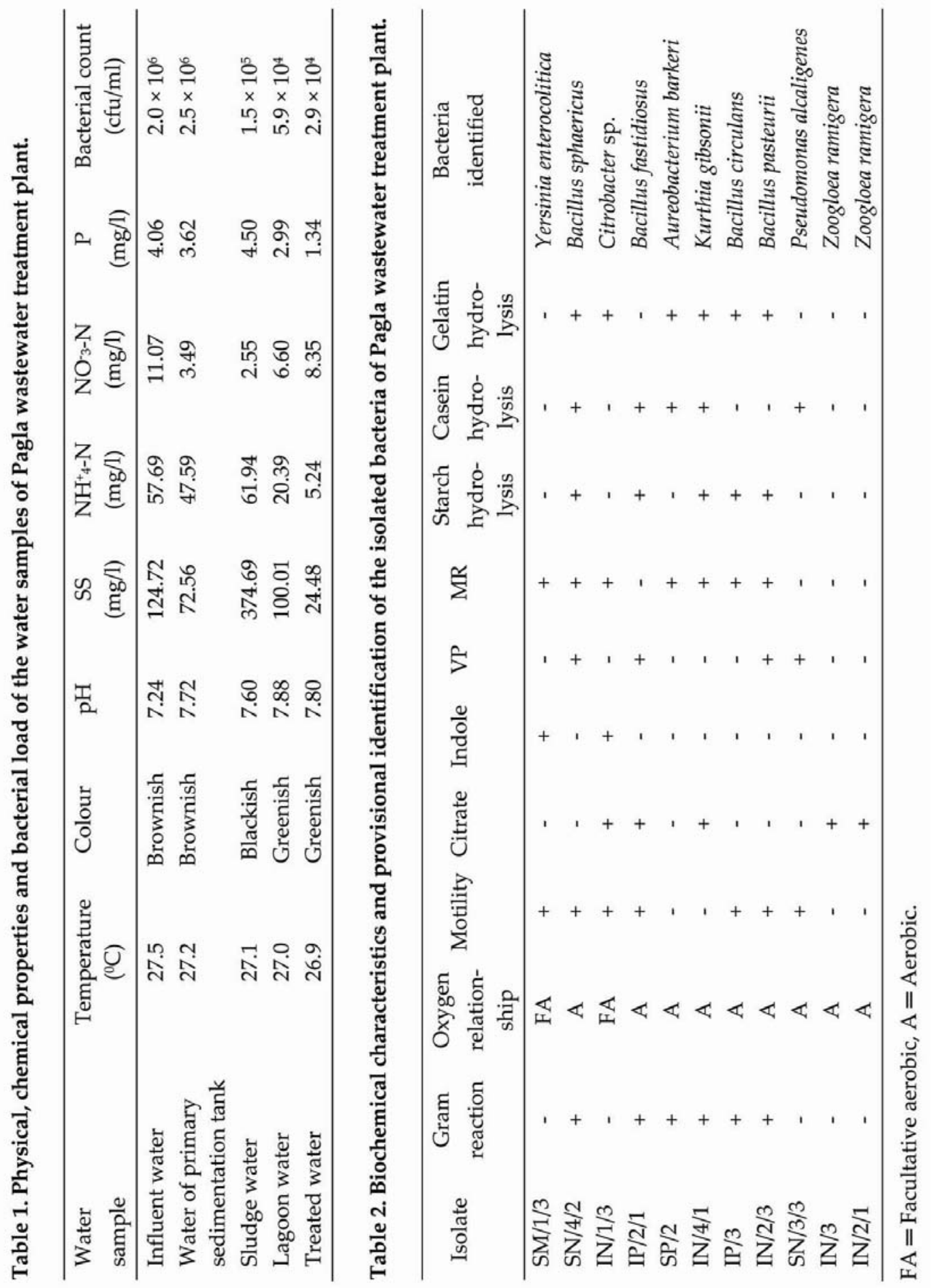


process. Gomes et al. (1991) reported the bacterial load from $1.25 \times 10^{4}$ to $6.2 \times 10^{4} \mathrm{cfu} / \mathrm{ml}$ from urea producing industrial cooling water reservoir.(24) Nishihara et al. (1997) reported the bacterial count as $2.0 \times 10^{6}, 1.0 \times 10^{4}$ and $6.6 \times 10^{4} \mathrm{cfu} / \mathrm{ml}$ in surface water from three different ponds in Japan ${ }^{(5)}$.

A total 62 discrete bacterial colonies were isolated which showed variation in their morphological characters. Out of these isolates, 11 were finally selected for their detailed studies for identification. The results of some of the biochemical tests are shown in Table 2. All isolates were aerobic and catalase positive. Most of the organisms were motile and methyl red positive and capable of hydrolyzing gelatin. Physiological and biochemical tests showed that the isolated organisms comprised of six different genera viz., Bacillus (4), Yersinia (1), Citrobacter (1), Aurebacterium (1), Kurthia (1), Pseudomonas (1) and Zoogloea (2). Under the genus Bacillus four species were present viz., Bacillus sphaericus, B. fastidious, B. circulans and B. pasteurii.

Bisz-Konazewska et al. (1985) reported from their investigation on nitrogenous wastewater treatment plant the presence of $20 \%$ Gram positive isolated bacterial strains but Gram negative rods belonged to Enterobacteriaceae (40\%) and Pseudomonas (17\%) ${ }^{(25)}$. Goud et al. (1985) reported the presence of Bacillus, Pseudomonas and Aeromonas in petrochemical industry effluent samples ${ }^{(26)}$. In this study both Gram positive rods and Pseudomonas were found to be associated with the domestic wastewater treatment plant. In another study it was found that isolated organisms from lagoon water were under the genera Bacillus, Staphylococcus, Pseudomonas, Streptococcus, Escherichia coli, Proteus, Klebsiella, Shigella etc ${ }^{(27)}$. Pseudomonas was present in most of the samples(28). It is evident from the existing information that Bacillus and Pseudomonas are common in most of the wastewater samples. Williams and Unz (1983) mentioned that Zoogloea ramigera is a possible indicator organism for organically polluted environment ${ }^{(29)}$. In the present findings Zoogloea was found in the wastewater samples.

Finally, it can be concluded that a good number of microorganisms were found to be associated with the bio-oxidation of the influent organic compounds. One of the important floc forming bacteria Zoogloea was present among the bacteria isolated. The genus Zoogloea along with other free flowing aerobic heterotrophic bacteria could play important role in the treatment of the domestic wastewater of the plant.

\section{References}

1. Glazer AN and H Nikaido 1994. Microbial biotechnology. Fundamentals of Applied Microbiology. W. H. Freeman and Company, New York. pp. 662.

2. Anonymous 1992. Standard Methods for the Examination of Water and Wastewater. APHA/AWWA/WPCF, Washington DC. pp. 756.

3. Viraraghavan $\mathrm{T}$ and $\mathrm{S}$ Tanjore 1994. The use of inexpensive and adsorbents to remove pollutants from wastewater. Environ. Sys. Rev. 36: 1-5.

4. Gupta AD 1993. Ground water contamination. Environ. Sys. Rev. 34: 1-5. 
5. Nishihara T, S Hasebe, J Nishikawa and M Kondo 1997. Biodegradation of aniline, anthracene, chlornitrophen, fenitrothion and linear alkylbenzene sulphonate in pond water. J. Appl. Microbiol. 82: 441-447.

6. Gschloessl T, I Michel, M Heiter, N Christan and R Verena 1997. Microscopic and enzymatic investigations on biofilms of wastewater treatment systems. Water Sci. Technol. 36 (1): 21-30.

7. Taber WA 1976. Waste water microbiology. Ann. Rev. Microbiol. 30: 263-277.

8. Bond PL., R Erhart, M Wagner, J Keller and LL Blackal. 1999. Identification of some of the major groups of bacteria in efficient and nonefficient biological phosphorus removal activated sludge systems. Appl. Environ. Microbiol. 65(9): 4077-4084.

9. Greenberg AE, JJ Connors, D Jenkins and MAH Franson. 1998. Standard methods for examination of water and wastewater (20 th $e d n$.). APHA. Washington DC. pp. 756.

10. Collins CH, and MP Lyne 1984. Microbiological Methods (5th edn.) Butterworth Co. (Publishers) Ltd. London. pp. 56-113.

11. Buchanon RC and NE Gibbons 1974. Bergey's Manual of Determinative Bacteriology (8th edn.) The Williams and Wilkins Company, Baltimore, USA. pp. 481-516.

12. Sneath PHA, NS Mair, ME Sharpe and JG Holt. 1986. Bergey's Manual of Systematic Bacteriology (9th edn. Vol. 2). The Williams and Wilkins Company, Baltimore, USA. pp. 1120-1125.

13. Eklund C and CE Lankford 1967. Laboratory Manual for General Microbiology. Prentice-Hall Inc. Englewood Cliffs, New Jersey. pp. 51-278.

14. Peltier GL, CE Georgi, LF Lindgren 1959. Laboratory Manual for General Bacteriology ( $5^{\text {th }}$ edn.) John Wiley and Sons. Inc. London. pp. 295.

15. Bryan H 1950. Manual of Methods for Pure Culture Study Bacteria. 12, Leaflet I-X.

16. Jackson ML 1973. Soil Chemical Analysis. Prentice-Hall of India Private Ltd. New Delhi. pp. 183-200.

17. Joergensen RG and PC Brookes 1990. Ninhydrin reactive nitrogen measurements of microbial biomass in 0.5M K ${ }_{2} \mathrm{SO}_{4}$ soil extracts. Soil Biol. and Biochem. 22: 1023-1027.

18. Murphy J and JP Riley 1962. A modified single solution method for determination of phosphate in natural waters. Anal. Chem. Acta. 27: 31-36.

19. Lloyd R 1992. Pollution and Freshwater fish. Blackwell Scientific Publications Ltd. pp. 3-75.

20. Kumar NJ and KP Krishnamoorthi. 1983. Evaluation of toxicity of ammoniacal fertilizer effluents. Environ. Pollution series A, Ecological and Biological. 30: 76-86.

21. WHO 1993. Guidelines for drinking water quality (2nd edn.). Geneva. 1: 25-100.

22. Pandey GM and GC Carney. 1989. Environmental Engineering. Tata McGraw Hill Publishing Co. Ltd. New Delhi. pp. 36-300.

23. Bangladesh Gazette 1997. Government of the Peoples Republic of Bangladesh, Ministry of Environment and Forestry. August 28.

24. Gomes DJ, S Sayeed, MM Hoq and SI Khan 1991. Microbial contaminants in an urea producing-industrial cooling-water reservoir. Bangladesh J. Microbiol. 8(2): 109-111. 
25. Bisz-Konazewska A, M Przytocka-Jusiak, M Rzeczycka and A Kowalska 1985. Bacterial microflora in Stichococcus bacillaris culture in nitrogenous-organic wastewaters. Acta. Microbiol. Pol. 34(3-4): 277-286.

26. Goud HD, LJ Parekh and CV Ramakrishnan 1985. Bacterial profile of petrochemical industry effluents. Environ. Pollution series A, Ecological and Biological. 39(1): 27-37.

27. Olukoya DK, ST Smith and MO Ilori 1997. Isolation and characterization of heavy metals resistant bacteria from Lagos lagoon. Folia Microbiologica. 42(5): 441-444.

28. Nunez L and J Moretton 2007. Disinfectant resistant bacteria in Buenos Aires city hospital wastewater. Brazilian J. Microbiol. 38: 644-648.

29. Williams TM and RF Unz 1983. Environmental distribution of Zoogloea strains. Water Res. 17: 779-780.

(Manuscript received on 27 July, 2011; revised on 15 November, 2011) 